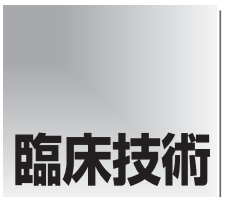

論文受付

2011 年 5 月 25 日

論文受理

2012 年 2 月 7 日

Code No. 331

\section{乳がんセンチネルリンパ節シンチグラフィにおける 半仰臥位正面像撮像体位の有用性}

\author{
市原裕紀 ${ }^{1,2}$ 小野口昌久 ${ }^{2}$ 日吉和久 ${ }^{1}$ 齋藤知子 $^{1}$ 阿部俊子 ${ }^{3}$ \\ 1 千葉県がんセンター核医学診療部 \\ 2 金沢大学大学院医学系研究科保健学専攻量子医療技術学講座 \\ 3 千葉県立佐原病院放射線科
}

\section{緒 言}

腫瘍から最初に流入するセンチネルリンパ節 (sentinel lymph node; SLN)に転移がなければ，その先の所属り ンパ節にも転移がないと診断できる.

乳がんにおいては, 手術は乳房切除から温存療法へ と侵襲性の低い技法へ転換しているが，このSLN に転 移が認められなければ腋窩リンパ節郭清は不要となり, さらなる低侵襲性の手術が選択され患者の負担軽減に 寄与する。この概念は Cabanas ら ${ }^{11}$ の陰茎がんに対する 報告から始まり, Morton ら²のメラノーマでのステージ ング手法, そして Krag ら ${ }^{3)}$ が乳がんに応用した。

乳がんにおけるSLNの同定には，放射性同位元素 (radioisotope; RI)を用い, 外科医が術中に体表面からガ ンマプローブにて検索する RI 法4) が近年では増加して いる。しかし，やみくもに体表面を検索するのでは時間 を要し, 複数の SLN やUren ら 5 が腋窩リンパ節以外に もトレーサの流入があると報告しているように，遠隔 SLN の同定を見逃す可能性がある. そのため, RI 法で 術前にガンマカメラを用いたセンチネルリンパ節シンチ グラフィ (sentinel lymphoscintigraphy; SLSG)を撮像し, 描出したSLN の位置や個数の情報を外科医が参照しな がら術中ガンマプローブ検索を行えば，SLNを迅速か つ見逃しなく同定できる.

しかし SLSGは, RI 注射部位の高集積体とSLNの

\title{
Usefulness of Imaging Posture Using Anterior View of the Half Supine Position for Sentinel Lymphscintigraphy in Patients with Breast Cancer
}

\author{
Hironori Ichihara, ${ }^{1,2}$ Masahisa Onoguchi, ${ }^{2 *}$ Kazuhisa Hiyoshi, ${ }^{1}$ Tomoko Saitou, ${ }^{1}$ and Toshiko Abe ${ }^{3}$ \\ ${ }^{1}$ Division of Nuclear Medicine, Chiba Cancer Center \\ ${ }^{2}$ Department of Quantum Medical Technology, Division of Health Sciences, Graduate School of Medical Science, Kanazawa \\ University \\ ${ }^{3}$ Department of Radiology, Chiba Prefectural Sawara Hospital
}

Received May 25, 2011; Revision accepted February 7, 2012

Code No. 331

\section{Summary}

Objectives: Sentinel lymphoscintigraphy(SLSG) is focused on the visualization of an injection site and lymph nodes. Therefore, an anterior view is effective in identifying the location of a lymph node easily. For this reason, we devised a new imaging method of anterior view (Modified Anterior View; MAV), and the usefulness was assessed. Methods: SLSG was obtained in 166 patients with breast cancer. In MAV imaging, patients were laid in an oblique position on a triangular styrene foam elevating the target axillary side. The detector was also leaned. Just after the MAV were imaged, the patient was shifted to the supine position and the SAV imaging was also performed using the same acquisition times. Results: The detectability of MAV and SAV was $92.42 \%$ and $81.99 \%$, respectively. However, the detectability of SAV showed the better value for the few cases which the lymph node detected by the inside of injection site. Conclusion: MAV may improve detectability of SLN. However, SAV is still required for a few cases in which lymph node is detected by the inside of injection site.

Key words: lymphscintigraphy, sentinel lymph node, breast cancer, imaging posture

*Proceeding author 


\section{Gamma camera}

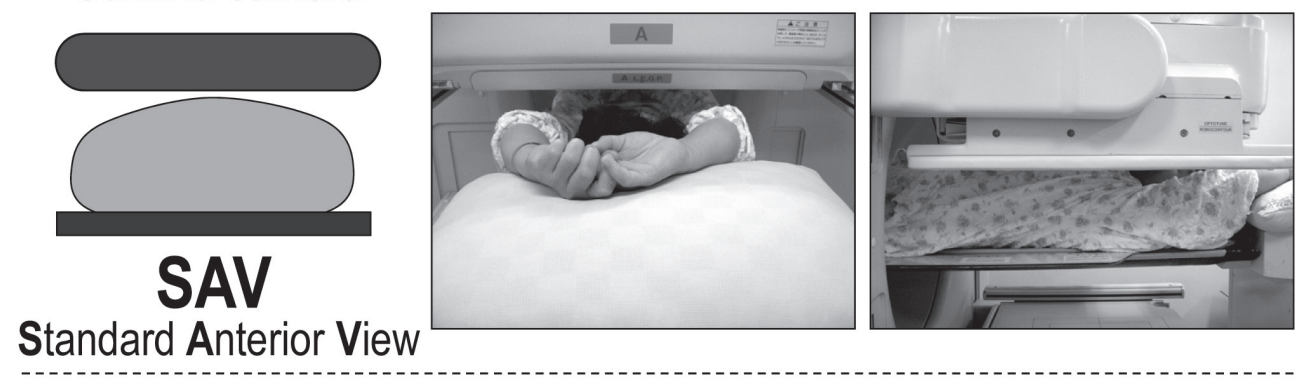

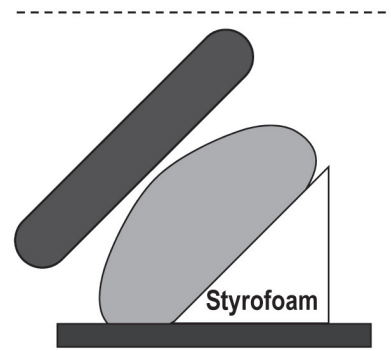

MAV Modified Anterior View
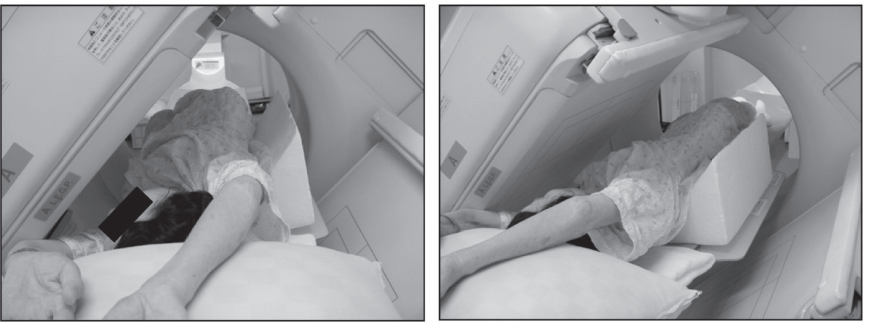

a

Fig. 1 Imaging posture of SAV (a) and MAV (b). Arm is elevated.
低集積体が同じ画像上に描出されるため，注射部位近 傍にSLN が存在すると高集積体からの散乱成分によっ て SLN の描出が覆い隠され，信頼性の低い情報を外科 医に提供することになり，ガンマプローブによるSLN の同定が不完全となる，よって，SLN が存在するリン パ節群から散乱成分の影響を回避させる必要があり, 乳がんにおいては腋窩リンパ節群が対象となる。

患者の体位を半仰臥位とした斜位像( modified oblique view of the axilla; MOVA)を撮像する方法が散 乱成分を回避でき，描出能が優れていると Haight $ら^{6}$ は報告しているが，SLSGで描出されるのは注射部位と リンパ節だけであり，しかも術中ガンマプローブ検索時 の外科医の視点は仰臥位にて正面を向いている患者で あるため, SLSG にて描出したSLN の位置情報を容易 に把握するには斜位像より正面像がよい，そこで，乳 がんにおけるSLSG に対し，高集積の RI 注射部位から 発生する散乱成分の影響の回避，および SLN の位置や 個数の描出能を向上させるための新たな正面像体位を 考案し, 臨床例で本法の有用性を検討した。

\section{1. 方 法}

\section{1-1 対 象}

細胞学的組織診断から乳がんと診断され, 腫瘍径が $30 \mathrm{~mm}$ 以下, 各種の画像診断で明らかな腋窩リンパ節 転移が認められずSLSG を撮像した症例に対し，ルー チンで行っている撮像体位(MOVA 掞よび仰臥位正面 像)に加えて新たに考案した正面像での追加撮像を行 い，検討対象である二つの正面像撮像体位の両方もし
くはどちらか一方で，SLSG 上から SLNであると考えら れる描出が確認できた 166 例(31-77 歳, 平均 55.2 歳, 全例女性，うち 1 例は両側乳がん) 243 個の描出 SLN を 対象とした。なお，MOVAも含めた全症例は 166 例 260 個の描出 SLN であった.

実施に際しては，患者に研究の概要および被ばく線 量の増加がないこと, 追加撮像に伴う 5 分程度の検査 時間延長を説明し同意を得ている。使用デー夕に関して は，個人を識別できる情報をすべて削除し連結不可能 匿名化を行った。

\section{1-2 使用機器と撮像条件}

低エネルギー沉用型コリメータ (low energy general purpose; LEGP) を装着した 2 検出器型ガンマカメラ： GCA7200A/UI(東芝メディカルシステムズ，日本)にて 撮像した。画像処理装置は, GMS5500(東芝メディカル システムズ，日本)を用いた。

腫瘍摘出手術当日朝に, $18.5 \mathrm{MBq} / 0.3 \mathrm{ml}$ の ${ }^{99 \mathrm{~m}} \mathrm{Tc}$ フチン酸を腫瘍直上皮下あるいは乳輪下に注射し、リ ンパ管にトレーサが流入するよう注射部位をマッサージ した，その後すぐに，マトリックスサイズ 512×512で 5 分間の撮像を行った。

\section{1-3 撮像体位}

比較検討する撮像体位は，仰臥位正面像 (standard anterior view；SAV)㧍よび新たに考案した半仰臥位正 面像(modified anterior view; MAV)である(Fig. 1).

MAV は，発泡スチロールを直角二等辺三角形に切り 
Table Measurement results of detected pattern and rate in SLSG

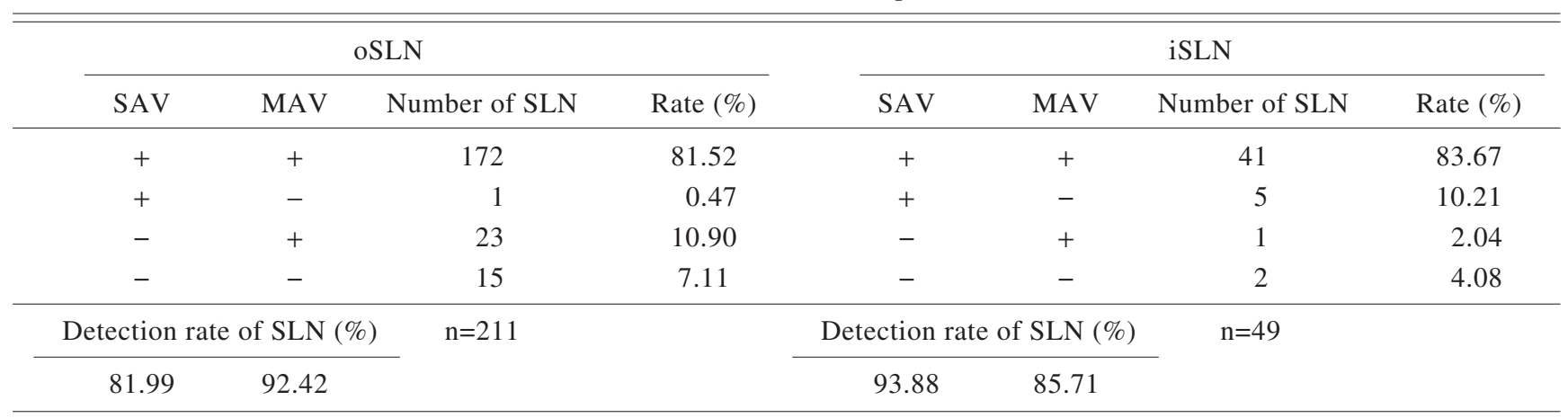

出した専用台を製作し，その台に対象腋窩側が上方と なるように体位を傾けた姿勢とした。傾斜角度は患者面 と検出器面が平行になるように調整しているため, 専用 台の傾斜角度と同等の 45 度ではない症例もあるが, お おむねそれに近い角度で撮像した。

体輪郭を描出するため, 撮像中に RI 注射後のシリン ジ先針残存放射能(約 $3.7 \mathrm{MBq}$ )を用い, 頸部から上 腕，腋窩から側腹部をトレースした，撮像は，MAV, SAVの順で行い, 撮像中にトレーサが流れたことによ る新たな SLN が描出された場合は再度体位を変えて撮 像した。

\section{1-4 データ解析}

CRT モニタ上から各撮像体位に㧍けるSLSG を観察 し，描出したSLNの個数を数え描出率を評価した。な お, 描出率の評価に関してのみ, MAVの正確な描出 率の算出のため, 本研究での検討対象外の撮像体位 (MOVA) も含めた 166 例 260 個の描出 SLN を対象と した.

SAV およびMAVの両方に描出が確認できた 213 個 のSLN に扔いて, RI 注射部位と描出 SLN の集積像間 距離を画像処理装置のルーラ機能から計測し, 式(1)で 示す減算値を算出した。

$D_{\mathrm{MAV}}=\mathrm{MAV}$ における集積像間距離 - SAVにおける集 積像間距離

式(1)の算出值からSLN の描出が確認できた全症例に おける評価のほかに, ブレストサイズおよび年齢の各因 子における検討も加えた。

ブレストサイズ別評価におけるサイズ分けは $\mathrm{S} \cdot \mathrm{M} \cdot \mathrm{L}$ とし，3名の放射線技師がそれぞれ担当した検査時に 主観的に決定した，年齢別評価では，ブレストサイズに よる交絡因子を除外するため，すべてのサイズに打ける 年齢別評価のほかに，ブレストサイズ別の年齢別評価 も加え, 相関係数と回帰直線を求めた。 これらの評価に
は, 描出 SLN の出現部位の違いによる検討を含めるた め, RI 注射部位の集積像から体外側に描出された SLN (outer SLN; oSLN) と体内側に描出されたSLN(inner SLN; iSLN)に区分けした，年齢別評価では, iSLNの標 本数が少なく正当な評価が不可能であったため除外し， oSLNのみで評価を行った，統計学的検討には, Bartlett 検定および $\mathrm{F}$ 検定にて等分散性が等しいと仮定された 群による比較には $\mathrm{t}$ 検定, 否定された群については Welch 検定を，それぞれ両側有意水準 0.05 で行った.

\section{2. 結 果}

\section{2-1 SLN 描出率}

各撮像体位における描出パターンと描出率を Table に示す、なお，SAV㧍よびMAVにて描出されなかっ たSLN 数は,ルーチン検査で撮像しているMOVAの みで描出できたSLN 数である。描出率は, OSLNでは $\operatorname{SAV}(81.99 \%), \operatorname{MAV}(92.42 \%)$ であったのに対して,

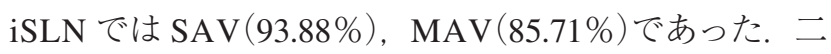
つの正面像のどちらでも SLN が描出できる症例が最も 多かったが, どちらか一方の正面像でしか SLN の描出 が確認できない症例もあった(Fig. 2).

\section{2-2 $D_{\mathrm{MAV}}$ の算出値}

$D_{\mathrm{MAV}}$ の算出值を Fig. 3 に示す. oSLNでは, MAV にすることで SAVに比べ平均で $18.1 \mathrm{~mm}$ 離れたが, iSLN では逆に $-1.5 \mathrm{~mm}$ と距離が縮まり, 検定にて有意 な差が認められた。

\section{2-3ブレストサイズにおける評価}

ブレストサイズに扔ける $D_{\mathrm{MAV}}$ の算出值を Fig. 4 に示 す。OSLNでは，ブレストサイズが大きくなるほど MAVの体位で距離が離れ，すべての対で有意な差が 認められた，iSLNでは，逆にサイズが小さいほど距離 が離れる傾向があったが, 有意な差はなかった。 


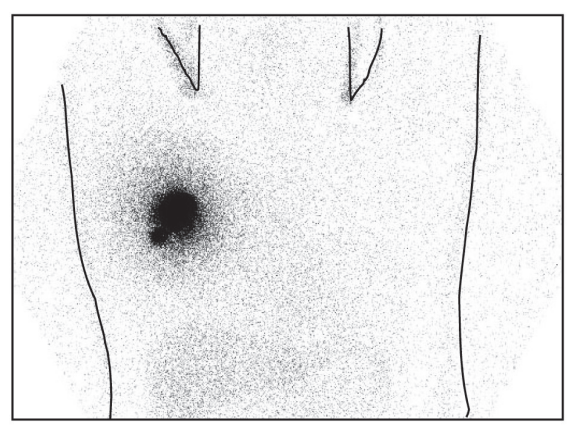

SAV

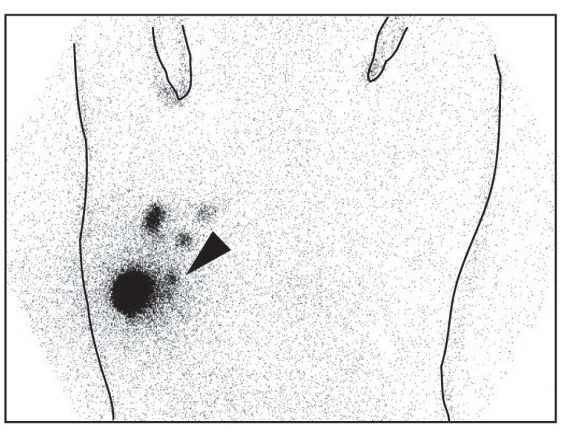

SAV

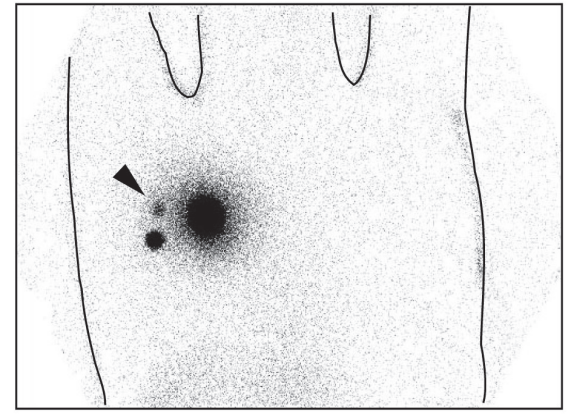

MAV

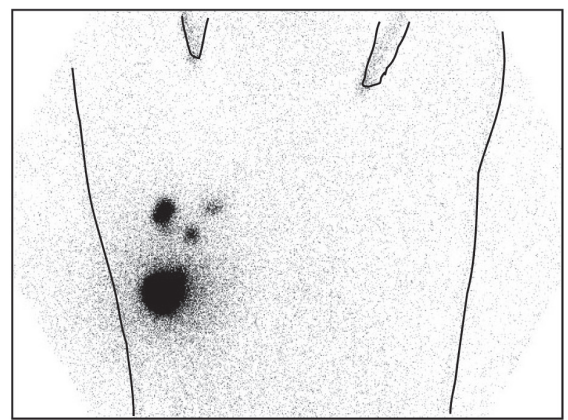

MAV a

b

Fig. 2 Clinical imaging of SAV and MAV.

(a) SLN was detected in the MAV but not detected in the SAV in the same patient.

(b) SLN was detected in the SAV but not detected in the MAV in the same patient.

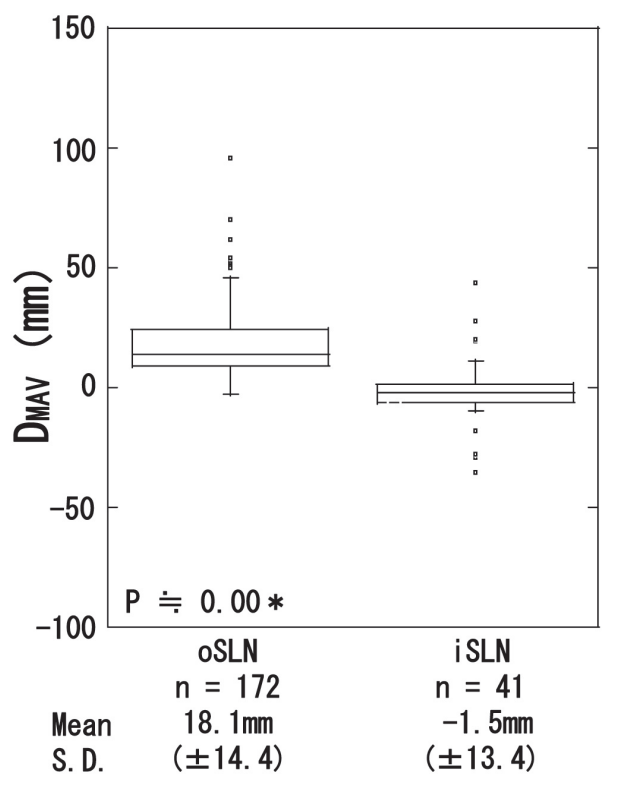

Fig. 3 Comparison of $D_{\mathrm{MAV}}$ between oSLN and iSLN.

*: $\mathrm{p}<0.05$
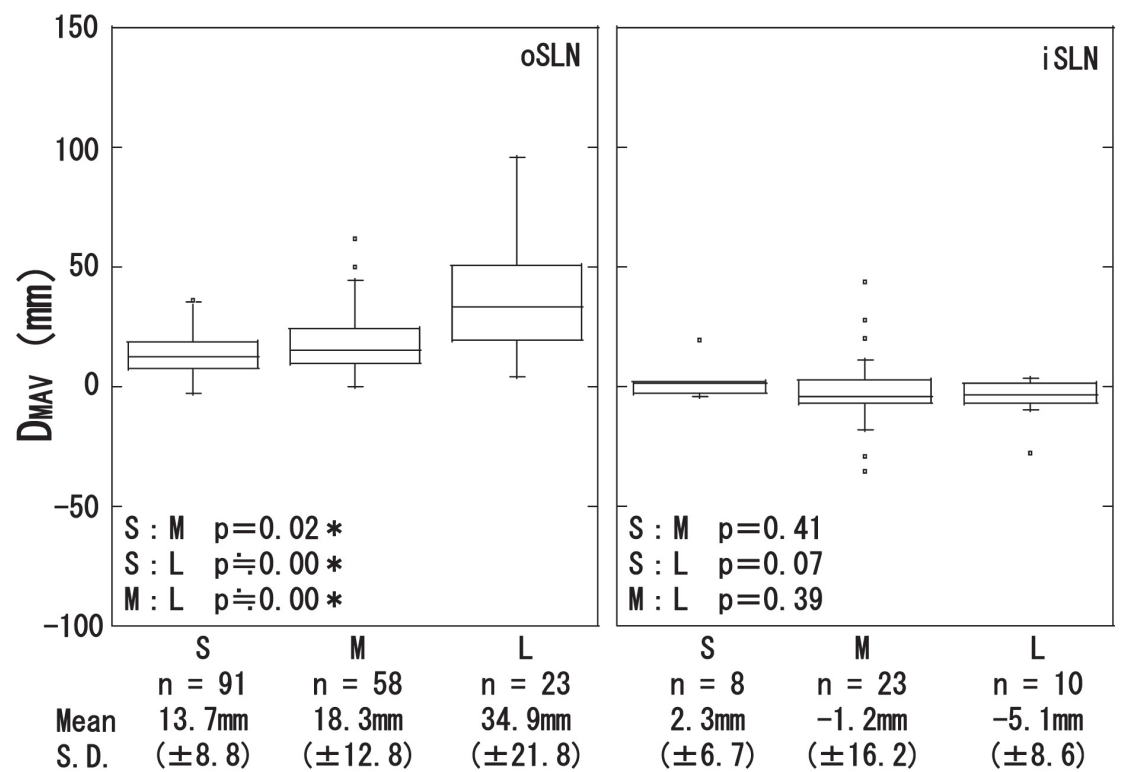

Fig. 4 Comparison of $D_{\mathrm{MAV}}$ between breast sizes.

$*: \mathrm{p}<0.05$

\section{2-4 年齢における評価}

年齢における $D_{\mathrm{MAV}}$ の算出值を Fig. 5 に示す。ブレス トサイズが $\mathrm{L} の$ 場合では，年齢と $D_{\mathrm{MAV}}$ の間に $r=0.35$ の弱い相関が認められた。

\section{3. 考察}

SLSG を行う目的は，術中にガンマプローブでSLN を検索する外科医に，描出した扮扮よその位置と個 数, 遠隔 SLN の有無についての広範囲な情報を提供す 


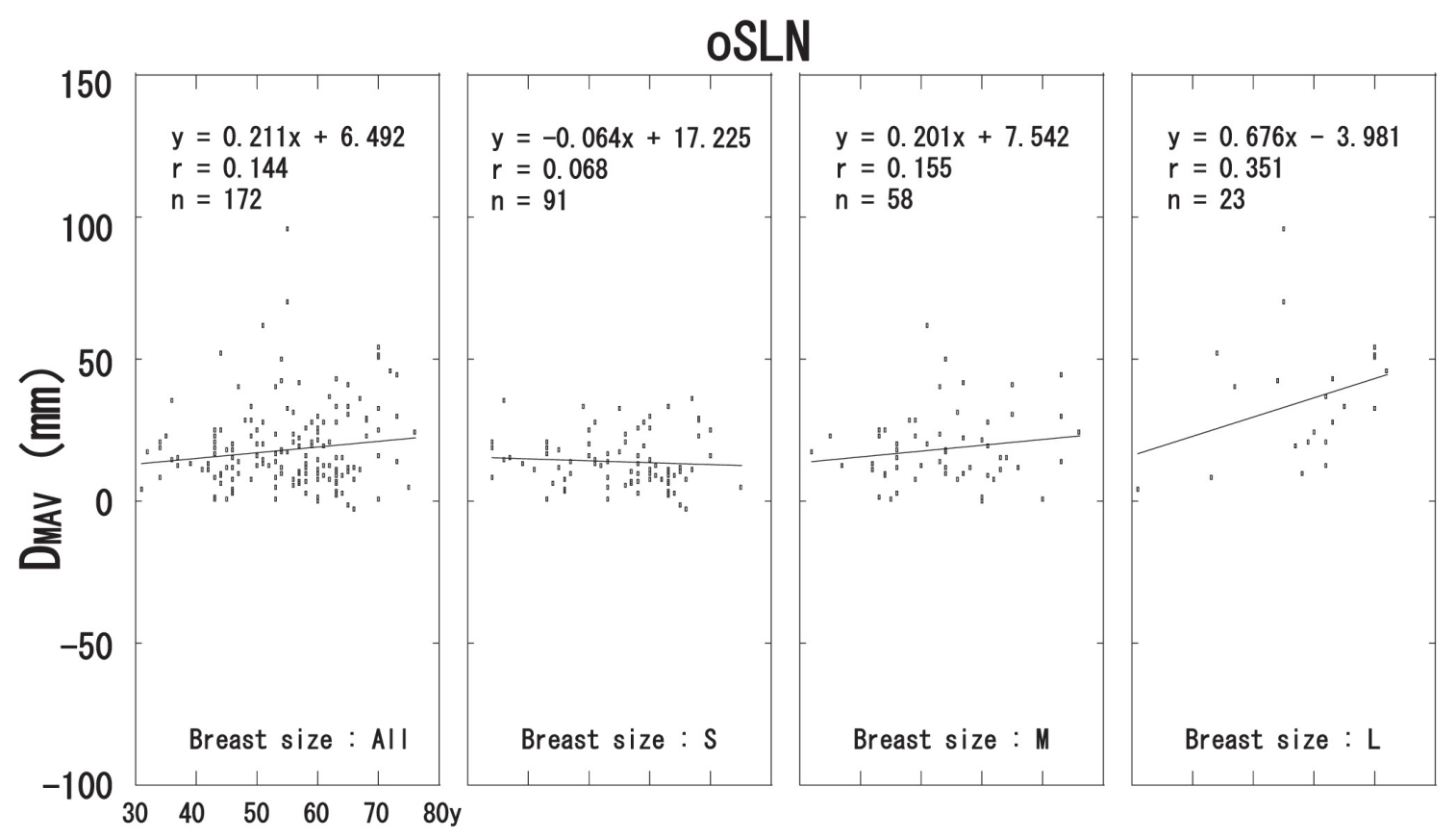

Fig. 5 Relationship between $D_{\mathrm{MAV}}$ and age in breast size.

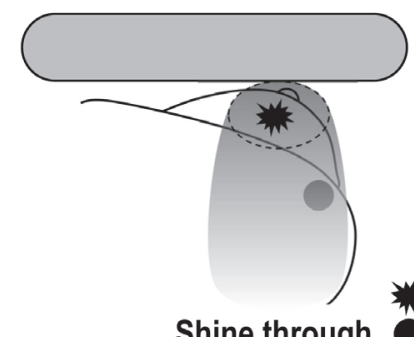

SAV

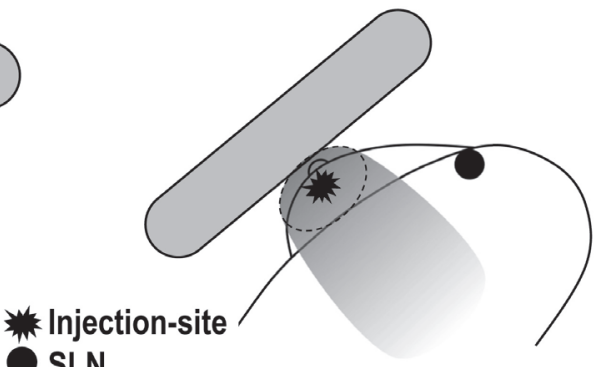

MAV $a \mid b$

Fig. 6 The anatomical position of SAV and MAV in oSLN.

(a) SLN covered by effect of scattered radiation in the SAV.

(b) SLN was detected by MAV because the breast shifted in inner.

ることである. 外科医が SLSG を参照し術中ガンマプ ローブ検索を行えば，SLNを見逃すことなく迅速に術 中同定することができる。しかし，高集積体である RI 注射部位近傍にSLN の集積が存在すると, 散乱成分の 影響で覆い隠され, 個数や位置の情報を外科医に提供 できず，同定できないSLN が発生する，スターアーチ ファクトの原因であるペネトレーションは, 中エネル ギーコリメータや本研究で用いた ${ }^{123} \mathrm{I}$ 製剂に対応する隔 壁の厚い LEGP コリメータを用いることによって改善さ れるが，それでも RI 注射部位近傍の散乱成分の影響 は残ってしまう。著者らのファントム実験では, RI 注 射部位を模した点線源(直径 $10 \mathrm{~mm} \cdot 18.5 \mathrm{MBq}$ )におい て, $20 \mathrm{~mm}$ 未満の距離では SLN の集積が散乱成分で 覆い隠されてしまった7).

著者らは, 半仰臥位斜位像での撮像がSLNの描出 能を最もよくする体位であると以前に報告したが8), 日
常行われている核医学イメージングでは用いない半仰 臥位で撮像された奥行きのある斜位像を平面像で視覚 化すると, 描出された SLN の位置情報を即座に把握す るのは難しい。そそのような問題点を改善するには正面像 が適しているが, 乳がんでは腋窩リンパ節が対象にな るため, 斜位像に比べると正面像の描出能は劣る。し かし半仰臥位の利点を応用できれば正面像でも良好な 結果が得られると考え, MAVの撮像体位を考案し, 正 面像での対比のため, SAVとの検討を行った.

MAVの描出率は oSLN で 92.42\%の良好な結果が得 られ, 今までの報告よりも高い描出率を示す正面像と なった ${ }^{9,10)}$. この描出率の向上は, Fig. 6 に示すように, 半仰臥位にすることで乳房が自重によって内側に傾くた め, 目的とする腋窩領域のリンパ節群から散乱成分を 遠ざけることができ, SAVにて覆い隠されていた SLN の描出が新たに確認できたためと考えられた。 


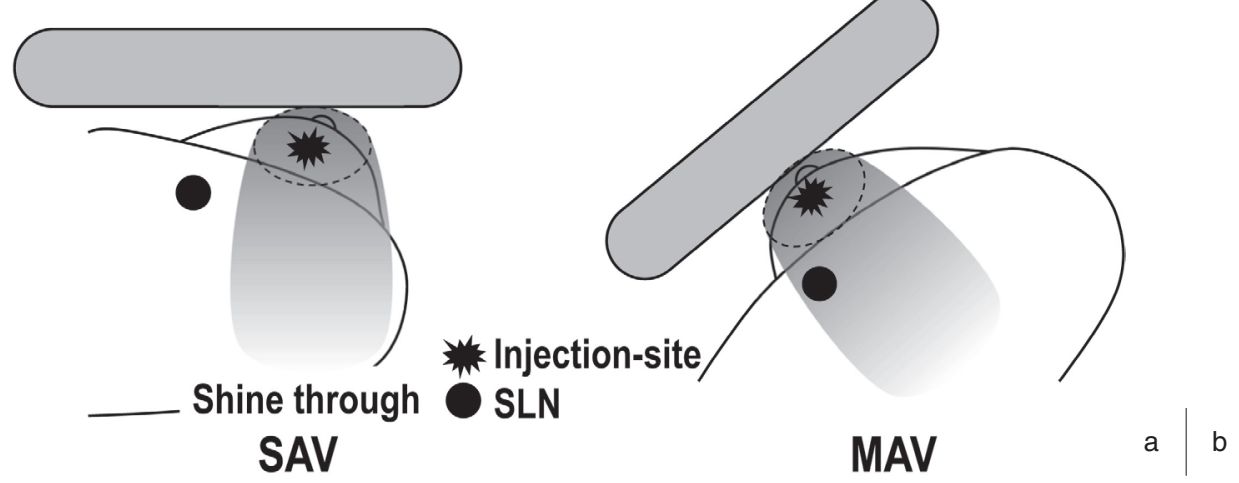

Fig. 7 The anatomical position of SAV and MAV in iSLN.

(a) SLN was detected by SAV.

(b) SLN covered by Shine through in MAV because the breast shifted in inner.

術前 SLSG の有用性に疑問を呈する報告11, 12) が見ら れるが，どれもSLN 描出率が術中ガンマプローブ検索 での同定率よりも低いことを指摘している。しかし本研 究で考案したMAVは, 描出率の向上に加え, 広範囲 かつ位置関係を容易に把握できる正面像である利点を 持ち得ているため有用な SLSG の撮像方法であると考 えられる。このように，oSLNでは良好な描出率を得た が，注意しなければならないのは，iSLNになると結果 が逆転され，最も描出率が高かったのはSAVになった ことである。 D DAV においても iSLN の結果は悪くなって おり，OSLNとiSLNとの間に有意な差が認められた。 これは Fig. 7 に示すように，RI 注射部位よりも内側に 描出したiSLNは，撮像体位を半仰臥位にすることで生 じる乳房の移動でSLN の描出が散乱成分に近づいてし まい，oSLN とは全く逆の現象が生じるためと思われる。

このiSLN の存在を考慮するにあたり，内胸側の胸骨 傍リンパ節群(internal mammary; IM)の重要性に関して 論議されており，転移している場合はトレーサの流入が ないと考えられ ${ }^{13,14)}$ ，SLSG は意味をなさないとの報告 がある ${ }^{15)}$. 本研究でも，IMへの集積が認められたのは 5/260 個(1.92\%)しかなく, IM の同定に関して SLSG で 期待をもつべきではない．しかし腋窩リンパ節群への集 積でも，RI 注射部位やブレストサイズによっては iSLN になる症例がある。また，散乱成分以外でも描出を妨 げる因子として複数個描出したSLN どうしが重なり合 い隠れてしまうこともある，よって，MAVのみではなく SAV を含めた複数方向で撮像することを推奨する.

ブレストサイズでみると，oSLNではサイズが大きい ほど距離が離れる良好な結果が得られた。これは半仰 臥位にすることで, 自重によって乳房が内胸側に移動す る割合が，ブレストサイズ大きくなるほど顕著になるこ
とに起因し, 男性乳がんや乳房厚のほとんどない症例 では，半臥位にすることよりもバストバンドなどで強制 的に乳房を内側に移動させるほうが有用であると考えら れる. iSLNでは，症例数が少ないために規則的な傾向 は認められなかったが，iSLNが OSLN とは逆にブレス トサイズが大きくなるほど，RI 注射部位とSLN 描出部 位間距離が短くなると思われる.

$D_{\mathrm{MAV}}$ と年齢の間には，ブレストサイズが $\mathrm{L}$ の場合で 弱い相関が見られ，加齢ごとに自重による乳房の移動 が大きくなった。これは, 乳腺組織が若年齢では発達 して扔り厚く密度もあり硬化しているが，閉経後は薄く 軟化するためだと思われる。ブレストサイズ $\mathrm{S}$ と M で の年齢による相関傾向がなかったのは，ブレストサイズ 別評価で述べた主観的サイズ分けで曖昧になってし まったことのほかに，半仰臥位にしたときの移動がもと もと小さいために, 数值として顕著に現れなかったこと が関係していると考えられる。

\section{4. 結 論}

乳がんに扔けるSLSG に対し，RI 注射部位の高集積 からの散乱成分の影響の回避，およびSLN の位置や個 数を描出するための撮像体位(MAV 法)を考案し, 臨床 例で有用性を検討した。

MAVの描出率はSAVより優れ，ブレストサイズが 大きいほど散乱成分の影響の回避が顕著であった。

この撮像体位は解剖学的位置の把握が容易な正面像 であることから，術中ガンマプローブ検索を行う外科医 の迅速な SLN の同定に寄与できることが示唆された. しかし，ごく稀に注射部位の内側にリンパ節が描出する ケースがあるため, SAV も含めた複数体位で撮像する ことを推奨する。 


\section{参考文献}

1) Cabanas RM. An approach for the treatment of penile carcinoma. Cancer 1977; 39(2): 456-466.

2) Morton DL, Wen DR, Wong JH, et al. Technical details of intraoperative lymphatic mapping for early stage melanoma. Arch Surg 1992; 127(4): 392-399.

3) Krag DN, Weaver DL, Alex JC, et al. Surgical resection and radiolocalization of the sentinel lymph node in breast cancer using a gamma probe. Surg Oncol 1993; 2(6): 335-339; discussion 340.

4) Glass EC, Essner R, Giuliano AE. Sentinel node localization in breast cancer. Semin Nucl Med 1999; 29(1): 57-68.

5) Uren RF, Howman-Giles RB, Thompson JF, et al. Mammary lymphoscintigraphy in breast cancer. J Nucl Med 1995; 36(10): 1775-1780.

6) Haigh PI, Hansen NM, Giuliano AE, et al. Factors affecting sentinel node localization during preoperative breast lymphoscintigraphy. J Nucl Med 2000; 41(10): 1682-1688.

7) 市原裕紀. センチネルリンパ節シンチグラフィの撮像を始め てみよう。日放技学誌 2010; 66(6): 678-685.

8）市原裕紀, 木下富士美, 日吉和久, 他. 乳がんセンチネル リンパ節シンチグラフィにおける撮像体位 (modified oblique view of the axilla：MOVA 法)の検討. 日放技学誌 2003; 59(6): 765-770.
9) Uren RF, Howman-Giles RB, Thompson JF, et al. Mammary lymphoscintigraphy in breast cancer. J Nucl Med 1995; 36(10): 1775-1780.

10) O'Hea BJ, Hill AD, El-Shirbiny AM, et al. Sentinel lymph node biopsy in breast cancer: initial experience at Memorial Sloan-Kettering Cancer Center. J Am Coll Surg 1998; 186(4): 423-427.

11) McMasters KM, Wong SL, Tuttle TM, et al. Preoperative lymphoscintigraphy for breast cancer does not improve the ability to identify axillary sentinel lymph nodes. Ann Surg 2000; 231(5): 724-731.

12) Burak WE, Walker MJ, Yee LD, et al. Routine preoperative lymphoscintigraphy is not necessary prior to sentinel node biopsy for breast cancer. Am J Surg 1999; 177(6): 445-449.

13) Noguchi M. Relevance and practicability of internal mammary sentinel node biopsy for breast cancer. Breast Cancer 2002; 9(4): 329-336.

14) Noguchi M. Internal mammary sentinel node biopsy for breast cancer: is it practicable and relevant? (Review). Oncol Rep 2002; 9(3): 461-468.

15) Noguchi M, Tsugawa K, Miwa K. Internal mammary chain sentinel lymph node identification in breast cancer. J Surg Oncol 2000; 73(2): 75-80.

Fig. $1 \quad \operatorname{SAV}(\mathrm{a})$ と $\mathrm{MAV}(\mathrm{b})$ の撮像体位

上肢は挙上する。

Fig. 2 SAV とMAVの臨床画像
(a)同一患者において，MAVでは描出できたSLN がSAVでは描出できなかった
(b)同一患者において，SAVでは描出できたSLN がMAVでは描出できなかった

Fig. 3 oSLN と iSLN 間における $D_{\mathrm{MAV}}$ の比較

*: $\mathrm{p}<0.05$

Fig. 4 ブレストサイズ間における $D_{\mathrm{MAV}}$ の比較

*: $\mathrm{p}<0.05$

Fig. 5 ブレストサイズ別での $D_{\mathrm{MAV}}$ と年齢間の相関関係

Fig. 6 oSLNにおけるSAV と MAV の解剖学的位置関係

(a)SAVでは，散乱線の影響によって SLN が覆い隠されてしまう。

(b)MAVでは, 乳房が内側に移動するためSLNが描出できる.

Fig. 7 iSLN における SAV と MAVの解剖学的位置関係

(a)SAVでは, SLNが描出できる。

(b)MAVでは，乳房が内側に移動するため，シャインスルーによって SLN が覆い隠されてしまう。

Table SLSGにお拈ける描出パターンと描出率の結果

問合先

干 920-0942 石川県金沢市小立野 5-11-80

金沢大学医薬保健研究域保健学系量子医療技術学講座 小野口昌久 